\title{
DZIENNKARSTWO 12
}

https://doi.org/10.19195/2082-8322.12.3

Roman Wróblewski

ORCID: 0000-0003-0142-9274

Uniwersytet Wrocławski

\section{Tematyka olimpijska w audycjach Rozgłośni Polskiej Radia Wolna Europa}

Celem niniejszego artykułu jest przedstawienie tematyki olimpijskiej w audycjach rozgłośni, która była kojarzona jednoznacznie w kontekście politycznym - jako medium wyraziście usytuowane po jednej ze stron globalnego konfliktu politycznego. Taką rozgłośnią było Radio Wolna Europa. Czy zatem w tematyce olimpijskiej w audycjach RWE widać tendencyjność związaną z aspektem politycznym funkcjonowania rozgłośni? Jeżeli odpowiedź na powyższe pytanie byłaby twierdząca, to w jaki sposób nadawca $\mathrm{w}$ medium zaangażowanym politycznie ujmuje treści polityczne w przekazie dotyczącym igrzysk olimpijskich? Jak kwestie ideologiczne wpływają na przekaz o najważniejszym wydarzeniu sportowym współczesnego świata?

\section{Idea olimpijska a polityka}

Idea igrzysk olimpijskich mówiła, że na czas ich rozgrywania ogłaszano pokój. Tradycja ta miała swój początek jeszcze w starożytności, kiedy to pokój boży między królami Elidy, Pisy i Sparty zobowiązywał Greków do przerwania walk na czas przygotowań do igrzysk i w czasie ich trwania. Co więcej, aby szczególnie zaakcentować trwałość owego porozumienia, wyryto je na spiżowym dysku' ${ }^{1}$. Tym samym aspekt sportowy był ważniejszy niż spory wojenne i oczywiście polityczne. Czasy nowożytne jednak zweryfikowały tę ideę i niejednokrotnie polityka wkraczała na areny sportowe, w tym także olimpijskie. Szczególnie było to widoczne poprzez bojkot igrzysk,

1 Starożytne idee. Ekecheira, http://www.olimpijski.pl/pl/134,starozytne-idee.html (dostęp: 29.12.2014). 
który w czasach nowożytnych ma tradycję sięgającą okresu sprzed wybuchu drugiej wojny światowej.

W 1936 roku republikańska Hiszpania organizowała Olimpiadę Ludową w Barcelonie. Miały to być zawody konkurencyjne w stosunku do igrzysk w Berlinie. Podłożem konfliktu były kwestie ideologiczne: republikańska Hiszpania nie zgadzała się na rozgrywanie zawodów w nazistowskich Niemczech. Uczestnikami zawodów nie byli jednak reprezentanci ekip narodowych, ale przedstawiciele różnych lewicowych organizacji. Olimpiada Ludowa miała się odbywać w dniach 19-26 lipca 1936 roku, jednak na dwa dni przed planowanym rozpoczęciem wybuchła w Hiszpanii wojna domowa i nie doszło do zawodów².

Cała seria bojkotów igrzysk olimpijskich rozpoczęła się przy okazji letnich igrzysk w Montrealu w 1976 roku. Dwadzieścia dwa państwa afrykańskie nie pojechały na zawody na znak protestu przeciwko niewykluczeniu przez MKOl ekipy Nowej Zelandii, której zawodnicy rugby odbyli tournée po RPA. Igrzyska te zbojkotował również Tajwan, któremu nie zezwolono na start pod nazwą: Republika Chin ${ }^{3}$.

Do kolejnego bojkotu doszło w roku 1980. Letnie igrzyska olimpijskie miały się odbyć w Moskwie, ale już w lutym 1980 roku prezydent USA Jimmy Carter zaapelował o bojkot zawodów. Powodem była agresja ZSRR na Afganistan w roku 1979. Ogółem igrzyska zbojkotowały sześćdziesiąt trzy kraje ${ }^{4}$. Część z ekip, które startowały, występowała pod flagą olimpijską. Dwadzieścia dziewięć reprezentacji państw bojkotujących igrzyska w Moskwie brało udział w konkurencyjnej lekkoatletycznej imprezie sportowej Liberty Bell Classic, która rozgrywana była w Filadelfii 16 i 17 lipca 1980 roku $^{5}$.

Kolejne letnie igrzyska olimpijskie miały się odbyć w roku 1984 w Los Angeles. I tym razem doszło do bojkotu, jednak w tym przypadku zawody bojkotowały państwa socjalistyczne. Moskwa ogłosiła bojkot igrzysk 8 maja 1984 roku. Oficjalnym pretekstem były obawy o bezpieczeństwo zawodników oraz „szowinistyczne nastroje

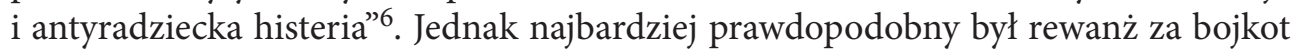
rozgrywanych cztery lata wcześniej igrzysk w Moskwie.

Polski Komitet Olimpijski podjął decyzję o przyłączeniu się do bojkotu 17 maja 1984 roku, na trzy dni przed upływem terminu zgłaszania reprezentacji narodowych do udziału w zawodach. W oświadczeniu PKOl-u można było przeczytać:

2 Olimpiada Ludowa, http://pl.wikipedia.org/wiki/Olimpiada_Ludowa (dostęp: 5.05.2014).

${ }^{3}$ Montreal 76, Moskwa 80, Los Angeles 84 - Olimpijskie skandale, dramaty i bojkoty, http://dzieje. $\mathrm{pl} /$ rozmaitosci/montreal-76-moskwa-80-los-angeles-84-olimpijskie-skandale-dramaty-i-bojkoty (dostęp: 5.05.2014).

${ }^{4}$ Ibidem.

5 Liberty Bell Classic, http://en.wikipedia.org/wiki/Liberty_Bell_Classic (dostęp: 5.05.2014).

6 1984Summer Olympics, http://en.wikipedia.org/wiki/1984_Summer_Olympics (dostęp: 26.04.2014). 
Zarząd Polskiego Komitetu Olimpijskiego na posiedzeniu odbytym w dniu 17 maja 1984 r. przy udziale przedstawicieli polskich związków sportowych, rozpatrzył kwestię udziału w Igrzyskach XXIII Olimpiady.

Po wszechstronnej dyskusji i uwzględnieniu wszystkich elementów sytuacji zaistniałej wokół Igrzysk w Los Angeles, PKOl postanowił nie zgłaszać polskiej reprezentacji do udziału w tych Igrzyskach. Mamy pełną świadomość, że jest to decyzja przykra, przede wszystkim dla zawodników, ale i dla milionów sympatyków sportu w naszym kraju. [...]

Niestety, postulaty i apele narodowych komitetów olimpijskich, zabiegi MKOl, powszechne zaniepokojenie opinii światowej - to wszystko zostało zignorowane przez administrację amerykańską, która ograniczyła się do ogólnikowych deklaracji, a nie podjęła rzeczywistych działań zapewniających bezpieczeństwo uczestnikom Igrzysk i niezbędną dla olimpiady atmosferę.

Powstała nieznośna sytuacja: bezkarnie działają dywersyjne organizacje stawiające sobie za cel niedopuszczenie do udziału w Igrzyskach sportowców radzieckich i innych krajów socjalistycznych, przygotowuje się werbowanie uciekinierów i gromadzi się na ten cel specjalne fundusze, grozi się prowokacyjnymi akcjami. [...] Znane są nam też przygotowania różnych antypolskich ośrodków w Los Angeles do prowadzenia działalności dywersyjnej wobec ekipy polskiej ${ }^{7}$.

Razem z ZSRR Igrzyska XXIII Olimpiady zbojkotowało piętnaście państw. Wśród nich znalazły się Libia i Iran, które bojkotowały zawody z innych powodów. Z państw tak zwanego bloku socjalistycznego wysłała swoich zawodników Rumunia. Zawody te zakończyły się zresztą dużym sukcesem sportowców rumuńskich, którzy zajęli w klasyfikacji medalowej drugie miejsce.

W opozycji do igrzysk w Los Angeles kraje bojkotujące zorganizowały cykl zawodów pod wspólną nazwą Przyjaźń-84. Ogłoszono je 24 maja 1984 roku. Jednak zawody te zorganizowano w nieco zmienionej formie niż igrzyska, które przyznawano wybranemu przez MKOl miastu. Zawody Przyjaźń- 84 były rozgrywane w lipcu i sierpniu w różnych państwach, które bojkotowały igrzyska w Los Angeles. Ich termin nie kolidował z igrzyskami w Los Angeles.

Warto jeszcze wspomnieć o jednym dramatycznym wydarzeniu na arenach olimpijskich, z jednoznacznym podtekstem politycznym, czyli „meczu we krwi”. Było to spotkanie $\mathrm{w}$ piłce wodnej między reprezentacjami Węgier i ZSRR podczas igrzysk olimpijskich w Melbourne 6 grudnia 1956 roku. Mecz został rozegrany wkrótce po stłumieniu przez wojska sowieckie powstania na Węgrzech (listopad 1956) i w związku z tym rywalizacja obu drużyn była odbierana w kontekście jednoznacznie politycznym. Publiczność zebrana w hali olimpijskiej kibicowała Węgrom. Wyrazem sympatii były flagi, których używali kibice węgierscy: miały one wycięte godło i nawiązywały do flag z powstania węgierskiego. Mecz obfitował w prowokacje z jednej i z drugiej strony. Gdy jeden z zawodników sowieckich rozciął łuk brwiowy Ervinowi

7 B., Jak Polacy nie pojechali na Igrzyska Olimpijskie Los Angeles 1984, http://numer10.blox. pl/2011/04/Jak-Polacy-nie-pojechali-na-Igrzyska-Olimpijskie.html (dostęp: 5.05.2014). 
Zádorowi i woda zabarwiła się na czerwono, mecz przerwano. Świat obiegły zdjęcia zakrwawionego węgierskiego waterpolisty.

\section{Rozgłośnia Polska Radia Wolna Europa}

Pierwsza audycja Rozgłośni Polskiej Radia Wolna Europa została nadana 3 maja 1952 roku. Przygotowania do niej trwały kilka lat. Sam pomysł powołania rozgłośni, która nadawałaby w językach narodowych i byłaby konkurencyjna w stosunku do mediów krajów za „żelazną kurtyną”, powstał w Stanach Zjednoczonych. Inicjatorem był Komitet Wolnej Europy, który na spotkaniu 1 czerwca 1949 roku „wyznaczył sobie za cel »udzielanie poparcia przywódcom politycznym i intelektualistom, przebywającym czasowo w USA, w poszukiwaniu wolności, której zostali pozbawieni we własnym kraju «" 8 . Wkrótce też — 4 lipca 1950 roku — pojawiły się audycje Radia Wolna Europa, które najpierw były nagrywane w Nowym Jorku, a następnie były przewożone do Niemiec, skąd miały swoją emisję radiową. Wśród tych audycji były także półgodzinne w języku polskim.

Pierwszą rozgłośnią narodową była rozgłośnia czechosłowacka (pierwsza audycja została wyemitowana 1 maja 1951 roku $)^{9}$. Organizacją Rozgłośni Polskiej zajął się w grudniu 1951 roku Jan Nowak, który uzyskał poparcie środowisk polonijnych: „Jego kandydaturę, wysuniętą przez delegaturę Rady Jedności Narodowej w USA, poparła RJN w Londynie" 10 . W skład pierwszego zespołu weszli między innymi: Aleksandra Stypułkowska (występowała pod pseudonimem Jadwiga Mieczkowska), Jerzy Szyszko-Bohusz, Michał Gamarnikow, Wojciech Trojanowski, Tadeusz Celt (występował pod pseudonimem Tadeusz Chciuk), Wiktor Budzyński, Wincenty Rapacki, Wacław Radulski, Roman Palestra, Jan Markowski, Wawrzyniec Czereśniewski, Tadeusz Nowakowski, Zbigniew Błażyński, Marek Walicki. Później dołączyli: ksiądz Tadeusz Kirschke i Gustaw Herling-Grudziński ${ }^{11}$.

$\mathrm{Na}$ szczególne wyróżnienie w kontekście tematu artykułu zasługuje obecność w zespole RWE Wojciecha Trojanowskiego, który jeszcze przed drugą wojną światową był znanym komentatorem sportowym Polskiego Radia, a wcześniej - lekkoatletą i startował w igrzyskach w Amsterdamie. Lata wojny spędził w oflagu w Woldenbergu. Po wojnie nie wrócił do Polski i rozpoczął współpracę z BBC.

W programie Rozgłośni Polskiej Jan Nowak składał zapewnienie niezależności: „Będzie to Rozgłośnia Polska. Polacy będą mówili do Polaków o naszych polskich

8 A. Perth-Grabowska, Powstanie Rozgłośni Polskiej Radia Wolna Europa, http://www.wolnaeuropa.pl/index.php?id=176\&id2=147 (dostęp: 30.03.2020).

9 Ibidem.

10 Ibidem.

11 Ibidem. 
sprawach. Nie będzie żadnej prewencyjnej cenzury amerykańskiej"12. Deklarowana niezależność była jednak w pewien sposób ograniczona, bo wytyczne organizatora rozgłośni, czyli Komitetu Wolnej Europy, mówiły, „by programy służyły interesom społeczności w Polsce, emigracji politycznej oraz interesom społeczeństwa amerykańskiego"13. Kontekst polityczny funkcjonowania RWE pojawia się w punkcie trzecim programu działania RWE sformułowanego przez Jana Nowaka: „Zadaniem Radia jest walka z propagandą i indoktrynacją, prostowanie fałszów, ukazywanie prawdy historycznej, dostarczanie pełnej informacji o tym, co dzieje się w Polsce i na świecie. Mamy podtrzymywać opór moralny i niezależną myśl”14. W myśl tego zapisu rozgłośnia miała być na swego rodzaju froncie wojny ideologicznej z mediami zniewolonej Polski.

\section{Przedmiot badań}

Przedmiotem badań były audycje Radia Wolna Europa udostępnione na stronie Polskiego Radia w dziale Radia Wolności ${ }^{15}$, gdzie prezentowane są nie tylko audycje RWE, ale również: Polskiej Sekcji BBC, Polskiej Sekcji Radia France Internationale, Głosu Ameryki. Spośród wszystkich udostępnionych audycji RWE wybrano tylko te, które dotyczyły igrzysk olimpijskich. Było to dwadzieścia pięć audycji. Nie jest to duża próba, jeśli wziąć pod uwagę to, że Rozgłośnia Polska RWE funkcjonowała przez ponad czterdzieści lat, a w tym czasie odbyło się osiem igrzysk letnich i osiem zimowych.

Materiał jest różnorodny gatunkowo. Wśród wyszukanych audycji są takie, jak: reportaż, rozmowa (wywiad), dyskusja, felieton, sprawozdanie, relacja, losowanie nagród, wspomnienie, informacje, opowieść radiowa.

Materiał jest także niejednorodny chronologicznie i dotyczy igrzysk letnich w Rzymie (1960), Meksyku (1968), Monachium (1972), Moskwie (1980), Los Angeles (1984), Seulu (1988), Barcelonie (1992) oraz igrzysk zimowych w Lake Placid (1980), Sarajewie (1984), Albertville (1992).

Różnorodność gatunkowa i chronologiczna pozwala na przedstawienie szerokiego obszaru tematyki olimpijskiej na falach Rozgłośni Polskiej Radia Wolna Europa. Na podstawie powyższych audycji można się przyjrzeć różnym etapom igrzysk. Są tam programy z przygotowań do zawodów oraz reportaże z inauguracji. Wydaje się, że mało jest w wyróżnionym zbiorze audycji, które są relacjami z samych zawodów,

12 A. Perth-Grabowska, Program działania Rozgłośni Polskiej RWE, http://www.wolnaeuropa.pl/index.php?id=179\&id2=147 (dostęp: 30.03.2020).

13 Ibidem.

14 Ibidem.

15 Zob. https://www.polskieradio.pl/68,Radia-Wolnosci (dostęp: 31.03.2020). Spis wybranych audycji znajduje się na końcu artykułu. 
jednak takie relacje są w innych programach. Przykładem może być program Igrzyska olimpijskie $w$ Monachium, który był poświęcony podsumowaniu igrzysk monachijskich, ale zawierał zbiór relacji ze zmagań Polaków. Relacji takich na antenie było oczywiście więcej ${ }^{16}$. Po zakończeniu igrzysk następowało ich podsumowanie. Programy RWE dotyczą nie tylko samych zmagań sportowych, wśród audycji są także takie, które można określić jako okołoolimpijskie, czyli tematycznie nawiązujące do igrzysk.

\section{Przygotowania do igrzysk}

Przygotowaniom do zawodów są poświęcone trzy audycje. W wyemitowanym w 1971 roku programie 502 dni do Igrzysk Olimpijskich ${ }^{17}$ Aleksander Menhard i Władysław Poniecki opisywali „największy w Europie plac budowy” przed igrzyskami w Monachium w roku 1972. Spacerując po budowie różnych obiektów olimpijskich, podawali szczegóły związane z budową infrastruktury igrzysk. Opisywali, jak wiele różnorodnych materiałów budowlanych zostało lub zostanie wykorzystanych przy wznoszeniu obiektów olimpijskich. $Z$ audycji przebija gigantomania i ton zachwytu: wszystkiego jest bardzo dużo, wszystko ma zdumiewać, zachwycać, jak na przykład tablice świetlne na stadionie olimpijskim, po raz pierwszy sterowane komputerowo, a na każdej będzie świeciło dwadzieścia pięć tysięcy dwudziestopięciowatowych żarówek. Budowana z okazji igrzysk autostrada, prowadząca na teren olimpijski, została w reportażu nazwana „czterożyłową szosą”.

Przygotowaniom do igrzysk jest poświęcona audycja nadana 1 stycznia 1984 roku Dyskusja redakcyjna ${ }^{18}$, w której brali udział Władysław Poniecki, Hubert Grzymała, Jerzy Różalski i Rafał Sikorski. Rozmówcy dyskutowali o nadchodzących zimowych igrzyskach w Sarajewie i letnich igrzyskach w Los Angeles.

Przed igrzyskami w roku 1984 Piotr Kobyliński został wysłany do Los Angeles, aby sprawdzić i opisać przygotowania do igrzysk w tym mieście. Jednak w tej relacji nie ma już tak entuzjastycznych zachwytów, jak przed igrzyskami w Monachium. Pojawiają się akcenty krytyczne i to już na samym początku, po przylocie na lotnisko, gdzie jest duży tłum, a dziennikarz zastanawia się, jak będzie podczas imprezy, gdy do Miasta Aniołów zjedzie dużo więcej gości. Reporter narzeka, że nie zapewniono

16 Wojciech Trojanowski wspominał w audycji z roku 1984, na rozpoczęcie zimowych igrzysk w Sarajewie, że jako korespondent brał udział w 15 igrzyskach. Wspomnienia z pracy korespondenta sportowego podczas igrzysk w Seulu opisał także Piotr Załuski (idem, U siebie... Moja Wolna Europa, Wrocław 2018, s. 156-173).

17502 dni do Igrzysk Olimpijskich (data emisji: 11.04.1971), https://www.polskieradio.pl/68/2461/ Audio/292342,502-dni-do-Igrzysk-Olimpijskich (dostęp: 22.04.2020).

18 Dyskusja redakcyjna (data emisji: 1.01.1984), https://www.polskieradio.pl/68/2461/Audio/307363, Dyskusja-redakcyjna (dostęp: 22.04.2020). 
mu przewodnika, który mówiłby w języku polskim. W relacji pojawiają się akcenty związane z kosztami igrzysk, właśnie igrzyska w Los Angeles bowiem miały się kierować „efektywnością ekonomiczną”, które to wyrażenie było podstawowym w tej olimpiadzie, a oznaczało liczenie się z kosztami ${ }^{19}$.

\section{Inauguracja igrzysk}

Kilka programów dotyczy samej inauguracji zawodów. Wyróżnia się tutaj relacja z inauguracji igrzysk w Rzymie w roku 1960, którą obserwował Wojciech Trojanowski ${ }^{20}$. Jego relacja, składana piękną polszczyzną, jest bardzo plastyczna i pełna kolorów. Dziennikarz opisywał wejście na stadion olimpijski kolejnych ekip sportowców. Zwracał uwagę na ich stroje, koncentrował się na kolorach. Słuchając jego opisu, można odnieść wrażenie, że ma się przed oczami barwny pochód drużyn z całego świata.

Wśród audycji, które dotyczą uroczystości inauguracji zawodów olimpijskich, są także dokumentalne zbiory z przemówieniami osób otwierających igrzyska. W programie z roku 1980 możemy posłuchać wystąpień prezydenta Międzynarodowego Komitetu Olimpijskiego lorda Michaela Morrisa Killanina oraz Leonida Breżniewa, I sekretarza KC KPZR, którzy otwierali igrzyska olimpijskie w Moskwie ${ }^{21}$. Z kolei zbiór wypowiedzi z roku 1984 zawiera fragmenty przemówień Petera Ueberrotha (przewodniczącego komitetu organizacyjnego igrzysk olimpijskich w Los Angeles), Juana Antonia Samarancha (przewodniczącego MKOl-u), Ronalda Reagana (prezydenta USA) oraz amerykańskiego lekkoatlety Edwina Mosesa, który w imieniu sportowców składał ślubowanie olimpijskie ${ }^{22}$.

\section{Relacje z zawodów w czasie trwania igrzysk}

W analizowanym zbiorze mało jest audycji, które były emitowane w czasie trwania igrzysk i dotyczyły bezpośrednio rywalizacji olimpijskiej. Ujęty w spisie Program specjalny z 9 sierpnia 1992 roku zawiera audycję Barcelona '92. Radiowy dodatek olimpij-

19 Los Angeles - miasto XXIII Olimpiady (data emisji: 22.04.1984), https://www.polskieradio. pl/68/2461/Audio/307440,Los-Angeles-miasto-XXIII-Olimpiady (dostęp: 22.04.2020).

20 Otwarcie olimpiady w Rzymie (data emisji: 25.08.1960), https://www.polskieradio.pl/68/2461/Audio/290705, Otwarcie-olimpiady-w-Rzymie (dostęp: 22.04.2020).

${ }^{21}$ Różne wypowiedzi (data emisji: 1.01 .1900 [1980 - RW]), https://www.polskieradio.pl/68/2461/ Audio/315393,Rozne-wypowiedzi (dostęp: 22.04.2020).

${ }^{22}$ Różne wypowiedzi (data emisji: 1.01.1900 [1984 - RW]), https://www.polskieradio.pl/68/2461/ Audio/315989,Rozne-wypowiedzi (dostęp: 22.04.2020). 
$s k i^{23}$. Jej autorem był Piotr Załuski, który przedstawiał bieżące informacje z danego dnia i omawiał wyniki Polaków oraz rozstrzygnięcia w innych zawodach, w których Polacy nie startowali.

W Różnych wypowiedziach, które są datowane na 30 lipca 1976 roku ${ }^{24}$, a więc w czasie trwania igrzysk w Montrealu, jest z kolei wypowiedź Ireny Szewińskiej, w której odnosiła się do kwestii związanych zarówno z przebiegiem kariery sportowej, jak i życiem osobistym.

\section{Podsumowanie igrzysk}

Zwykle po zakończeniu rywalizacji sportowej następowały podsumowania zawodów i kilka audycji jest poświęconych właśnie temu.

W nadanej w 1972 roku audycji Igrzyska Olimpijskie w Monachium ${ }^{25}$ Władysław Poncet, Kazimierz Wilczyński i Jan Jasiewicz podsumowują zakończone igrzyska. Szczególnie akcentują starty Polaków. W programie jest kilka relacji z aren olimpijskich, między innymi z dekoracji medalowej Władysława Komara, który zdobył złoty medal w rzucie kulą. Można wysłuchać sprawozdania z końcówki finałowej walki Jana Szczepańskiego w boksie, który również zdobył złoty medal, oraz z ceremonii dekoracji Polaka. Spośród wszystkich sukcesów polskich zawodników wyróżniają złoty medal dla reprezentacji Polski w piłce nożnej.

W roku 1988, po igrzyskach w Seulu, na antenie RWE wyemitowano program Zakończenie XXIV letnich igrzysk olimpijskich $w$ Seulu ${ }^{26}$, w którym była rozmowa Konrada Tatarowskiego i Władysława Ponceta z Hubertem Grzymałą, Jackiem Kaczmarskim i Krzysztofem Witoniem. Rozmowa była przerywana refleksjami Piotra Załuskiego, który był w tym czasie reporterem RWE na igrzyskach w Korei. Dyskutanci wskazywali na rozrost i gigantyzm - jak to nazwali - igrzysk, czyli coraz więcej bardzo różnorodnych dyscyplin, co nie wpływało - ich zdaniem - pozytywnie na kształt zawodów. Szczególnie zwracał uwagę na to Piotr Załuski. Inni rozmówcy, którzy oglądali igrzyska $w$ telewizji, nie mieli aż tak niekorzystnego wrażenia. Tłumaczyli, że wynika to z możliwości mediów, które coraz bardziej wpływały na sferę organizacyjną zawodów.

23 Program specjalny (data emisji: 9.08.1992), https://www.polskieradio.pl/68/2461/Audio/316726,Program-specjalny (dostęp: 22.04.2020).

24 Różne wypowiedzi (data emisji: 30.07.1976), https://www.polskieradio.pl/68/2461/Audio 1315917,Rozne-wypowiedzi (dostęp: 22.04.2020).

25 Igrzyska Olimpijskie w Monachium (data emisji: 17.09.1972), https://www.polskieradio.pl/68/2461/ Audio/292373,Igrzyska-Olimpijskie-w-Monachium (dostęp: 22.04.2020).

26 Zakończenie XXIV letnich igrzysk olimpijskich $w$ Seulu (data emisji: 2.10.1988), https://www.polskieradio.pl/68/2461/Audio/310354,Zakonczenie-XXIV-letnich-igrzysk-olimpijskich-w-Seulu (dostęp: 22.04.2020). 
Ważnym wątkiem w dyskusji był skandal dopingowy Bena Johnsona. Redaktor Załuski stwierdzał, że były to igrzyska, na których była większa liczba afer dopingowych, ale wynikało to $\mathrm{z}$ lepszej kontroli i większej liczby skontrolowanych zawodników. Dyskutanci wskazywali na to, że afery dopingowe sięgały nie tylko samych sportowców, ale także ich zaplecza: trenerów, sztabów, lekarzy.

W kontekście występu polskich zawodników, którzy zdobyli tylko szesnaście medali, rozmówcy narzekali, że jest to skutek kryzysu polskiego sportu. Żadnego medalu nie zdobyli Polacy w lekkoatletyce. Żadnego w grach zespołowych, bo polskie drużyny nie zakwalifikowały się na turniej olimpijski. Komentatorzy, mówiąc o receptach na ten stan rzeczy, wskazywali potrzebę zachęt dla młodego pokolenia do uprawiania sportu. Według rozmówców sposobem na skłonienie do uprawiania sportu mogłyby być nagrody, w tym także pieniężne.

Okazją do podsumowania igrzysk był zazwyczaj koniec roku kalendarzowego. Tak było w roku 1980, kiedy to odbywały się igrzyska zimowe w Lake Placid i letnie w Moskwie. W audycji Sport w 1980 roku ${ }^{27}$ jest mowa między innymi właśnie o zawodach olimpijskich. Przypomniano najważniejszych bohaterów tych zawodów, na przykład reprezentanta USA Erica Heidena, który zdobył pięć złotych medali w łyżwiarstwie szybkim. W kontekście igrzysk moskiewskich wspomniano także o bojkocie zawodów, ale najważniejsze były medale Polaków i na nich skupiono największą uwagę.

\section{Audycje okołoolimpijskie}

Oprócz audycji, które dotyczyły bezpośrednio zmagań olimpijskich, na antenie pojawiały się także inne, które wpływały na propagowanie idei olimpijskiej. Przykładami mogą być konkursy, jakie prowadzili w roku 1992 Piotr Załuski i Konrad Tatarowski. Pierwszy z konkursów był ogłoszony na początku roku i był związany z igrzyskami zimowymi w Albertville ${ }^{28}$, drugi zaś w połowie roku przy okazji letnich igrzysk w Barcelonie ${ }^{29}$. Nagrodami w drugim konkursie były albumy o słynnym architekcie hiszpańskim Gaudim oraz książka Olimpijska gorączka Mieczysława Minkiewicza. Książka ta była tematem wywiadu Jana Tyszkiewicza z jej autorem w styczniu 1992

27 Sport w 1980 roku (data emisji: 26.12.1980), https://www.polskieradio.pl/68/2461/Audio/306685 ,Sport-w-1980-roku (dostęp: 22.04.2020).

${ }^{28}$ Czasy zwykłe, czasy ciekawe (cz. 121) (data emisji: 24.02.1992), w tej audycji był Radiowy dodatek olimpijski, https://www.polskieradio.pl/68/2461/Audio/347120,Czasy-zwykle-czasy-ciekawe-cz121 (dostęp: 22.04.2020).

29 Open Slot (data emisji: 20.08.1992), https://www.polskieradio.pl/68/2461/Audio/316750,Open-Slot (dostęp: 22.04.2020). 
roku w audycji Godzina bez Kwadransa ${ }^{30}$. Audycja była przeplatana fragmentami Symfonii olimpijskiej Zbigniewa Turskiego ${ }^{31}$.

Przykładem innej audycji, która nie dotyczyła bezpośrednio konkretnych zawodów, jest wyemitowana 25 grudnia 1956 roku opowieść radiowa oparta na utworze Jana Parandowskiego Dysk olimpijski ${ }^{32}$. Było to słuchowisko, w którym wykorzystano fragmenty utworu Parandowskiego, na wstępie zaś zacytowano fragment Lauru olimpijskiego Kazimierza Wierzyńskiego. Przy tej okazji warto przypomnieć, że podczas pierwszych nowożytnych igrzysk, w latach 1912-1948, oprócz zawodów sportowych organizowano również konkursy w dziedzinie sztuki i literatury ${ }^{33}$. Kazimierz Wierzyński otrzymał złoty medal w 1928 roku za tomik poetycki Laur olimpijski ${ }^{34}$.

Do kategorii audycji okołoolimpijskich można też zaliczyć felieton profesora Krzyżanowskiego Olimpijczyk ${ }^{35}$. Właściwie jest to słuchowisko, którego głównym tematem jest historia rodziny młodego kolarza (dziadek - rozstrzelany w Katyniu, ojciec — zesłany w głąb sowieckiej Rosji), który stara się o kwalifikację olimpijską.

\section{Wojciech Trojanowski}

Osobno należy wspomnieć o Wojciechu Trojanowskim, legendarnym dziennikarzu sportowym, o którym nie sposób nie napisać przy omawianiu tematyki olimpijskiej na antenie RWE. Z rozgłośnią był związany od jej powstania, ale karierę dziennikarską rozpoczynał w Polskim Radiu jeszcze przed drugą wojną światową. Po wyzwoleniu z niewoli niemieckiej został na Zachodzie, gdzie początkowo pracował w BBC. Przed wojną startował na igrzyskach w Amsterdamie, a jako dziennikarz był korespondentem radiowym podczas igrzysk w Berlinie ${ }^{36}$.

30 Godzina bez Kwadransa (data emisji: 19.01.1992), https://www.polskieradio.pl/68/2461/Audio 1316280,Godzina-bez-Kwadransa (dostęp: 22.04.2020).

31 Za utwór ten Zbigniew Turski otrzymał złoty medal na Olimpijskim Konkursie Sztuki i Literatury podczas XIV Letnich Igrzysk Olimpijskich w Londynie — zob. Zbigniew Turski 1908-1979 [biogram], https://pwm.com.pl/pl/kompozytorzy_i_autorzy/5250/zbigniew-turski/index.html (dostęp: 26.04. 2020).

32 Wieniec olimpijski (data emisji: 25.12.1956), https://www.polskieradio.pl/68/2461/Audio/290443, Wieniec-olimpijski (dostęp: 22.04.2020).

33 Polscy artyści na Olimpijskich Konkursach Sztuki: 1928-1948, https://culture.pl/pl/artykul/polscy-artysci-na-olimpijskich-konkursach-sztuki-1928-1948 (dostęp: 26.04.2020).

34 K. Wierzyński, Laur olimpijski, https://www.olimpijski.pl/Media/files/Wierzynski_Laur\%20 Olimpijski.pdf (dostęp: 26.04.2020).

35 Felieton prof. Jerzego Krzyżanowskiego (data emisji: 1.01.1900 [1980? - RW]), https://www.polskieradio.pl/68/2461/Audio/326171,Felieton-prof-Jerzego-Krzyzanowskiego (dostęp: 22.04.2020).

${ }^{36}$ Losy Wojciecha Trojanowskiego opisał Bogdan Tuszyński (idem, Wojciech Trojanowski (19041988), „Kwartalnik Historii Prasy Polskiej” 29, 1990, nr 2, s. 95-113). 
Gdy został pracownikiem Radia Wolna Europa, regularnie komentował zawody olimpijskie. Próbkę jego kunsztu dziennikarskiego możemy poznać w relacji z inauguracji igrzysk olimpijskich w Rzymie, o czym wspomniano wcześniej. Ciekawy jest także wywiad, jaki przeprowadził z Emilem Zátopkiem podczas igrzysk w Meksyku ${ }^{37}$. Okoliczności przeprowadzenia tego wywiadu były nietypowe: w jadącym autobusie, gdzie przez przypadek Trojanowski spotkał Zátopka, honorowego gościa igrzysk meksykańskich, który akurat jechał z żoną. Trojanowski w rozmowie pytał o wpływ, jak powiedział, „trudnej sytuacji” na czechosłowackich sportowców. Eufemizm „trudna sytuacja” dotyczył wkroczenia wojsk Układu Warszawskiego w sierpniu w 1968 roku do Czechosłowacji. Zátopek, ku zdziwieniu samego Trojanowskiego, części wywiadu udzielił w języku polskim. W audycji Trojanowski mówi, że po zakończeniu rozmowy i wyłączeniu mikrofonu „rozmawiali o sprawach, które nic ze sportem nie miały wspólnego”. Można się tylko domyślać, że chodziło o sytuację polityczną w zajętej Czechosłowacji.

Wśród uwzględnionych w zestawieniu audycji są te, których bohaterem jest on sam i jego praca dziennikarska: Audycja sportowa (dwie części) ${ }^{38}$ - rozmowa T. Nowakowskiego z W. Trojanowskim przed jego wyjazdem na igrzyska w Meksyku; Rozmowa $z$ Wojciechem Trojanowskim ${ }^{39}$; Studio Olimpijskie ${ }^{40}$. W rozmowach tych Trojanowski opowiada o igrzyskach, podczas których pracował jako reporter monachijskiej rozgłośni. Mówi barwnie, jest kopalnią olimpijskich anegdot.

W audycji Polskie złote medale olimpijskie ${ }^{41}$ wspomina historię polskich zwycięstw olimpijskich, które relacjonował na falach eteru. W mistrzowski sposób, jakby malując głosem, oddaje nastrój chwili: od pełnych napięcia momentów walki, rywalizacji po wzniosły moment zwycięstwa. Jego największą bohaterką była Irena Szewińska, którą opisywał podczas biegu po złoto na igrzyskach w Meksyku.

\section{Zakończenie}

Czy polityczny kontekst funkcjonowania Rozgłośni Polskiej Radia Wolna Europa miał wpływ na obraz zmagań sportowych na arenach olimpijskich w jej audycjach?

37 Rozmowa $z$ Emilem Zatopkiem (data emisji: 22.10.1968), https://www.polskieradio.pl/68/2461/ Audio/292137,Rozmowa-z-Emilem-Zatopkiem (dostęp: 22.04.2020).

38 Audycja sportowa (data emisji: 6.10.1968), https://www.polskieradio.pl/68/2461/Audio/291895,Audycja-sportowa (dostęp: 22.04.2020); Audycja sportowa (data emisji: 6.10.1968), https://www.polskieradio. pl/68/2461/Audio/291896,Audycja-sportowa (dostęp: 22.04.2020).

39 Rozmowa $z$ Wojciechem Trojanowskim (data emisji: 16.04.1979), https://www.polskieradio. pl/68/2461/Audio/299162,Rozmowa-z-Wojciechem-Trojanowskim (dostęp: 22.04.2020).

40 Studio Olimpijskie (data emisji: 7.02.1984), https://www.polskieradio.pl/68/2461/Audio/307402,Studio-Olimpijskie (dostęp: 22.04.2020).

41 Polskie złote medale olimpijskie (data emisji: 1.04.1972), https://www.polskieradio.pl/68/2461/Audio/292192,Polskie-zlote-medale-olimpijskie (dostęp: 22.04.2020). 
Wydaje się, że nie. Co prawda odpowiedź ta formułowana jest na podstawie niepełnego zbioru programów, a kilka z nich powstało po zakończeniu okresu „zimnej wojny", ale ten wybór pozwala na zarysowanie tematyki olimpijskiej na falach RWE.

W audycjach RWE widoczne jest profesjonalne oddzielenie treści sportowych od polityki. Dziennikarze znają się na sporcie i w ich relacjach czy komentarzach rywalizacja sportowa jest najważniejsza. Można by sądzić, że w audycjach rozgłośni, która była na pierwszej linii frontu informacyjnego, będzie się pojawiał negatywny i polityczny kontekst występów sportowców czy reprezentacji kraju, który oficjalnie nazywał się: Polska Rzeczpospolita Ludowa i rządzony był przez partię komunistyczną. Tymczasem tak nie jest. Na pierwszym miejscu jest sport. Jest kibicowanie Polakom, mimo że startowali oni jako reprezentanci PRL-u. Jeżeli nawet pojawiają się głosy nawiązujące do świata polityki, to są one stonowane i chyba najlepszym komentarzem są cytowane wcześniej słowa Wojciecha Trojanowskiego, który po zakończeniu rozmowy z Emilem Zátopkiem powiedział, że wtedy „rozmawiali o sprawach, które nic ze sportem nie miały wspólnego", a przecież, znając kontekst historyczny tej chwili, można było się łatwo domyślić, że chodziło o politykę. Może także to, że w rozgłośni pracował słynny dziennikarz sportowy, który dzięki swojemu kunsztowi radiowemu oraz ogromnemu doświadczeniu i obyciu w świecie sportu wynosił relacje ze stadionów na wyżyny dziennikarstwa, nadało taki wyjątkowy, profesjonalny rys tematyce sportowej w Radiu Wolna Europa.

\section{Bibliografia}

1984 Summer Olympics, http://en.wikipedia.org/wiki/1984_Summer_Olympics (dostęp: 26.04.2014).

B., Jak Polacy nie pojechali na Igrzyska Olimpijskie Los Angeles 1984, http://numer10.blox.pl/2011/04/ Jak-Polacy-nie-pojechali-na-Igrzyska-Olimpijskie.html (dostęp: 5.05.2014).

Liberty Bell Classic, http://en.wikipedia.org/wiki/Liberty_Bell_Classic (dostęp: 5.05.2014).

Montreal 76, Moskwa 80, Los Angeles 84 - Olimpijskie skandale, dramaty i bojkoty, http://dzieje.pl/rozmaitosci/montreal-76-moskwa-80-los-angeles-84-olimpijskie-skandale-dramaty-i-bojkoty (dostęp: 5.05.2014).

Olimpiada Ludowa, http://pl.wikipedia.org/wiki/Olimpiada_Ludowa (dostęp: 5.05.2014).

Perth-Grabowska A., Powstanie Rozgłośni Polskiej Radia Wolna Europa, http://www.wolnaeuropa.pl/ index.php?id=176\&id2=147 (dostęp: 30.03.2020).

Perth-Grabowska A., Program działania Rozgłośni Polskiej RWE, http://www.wolnaeuropa.pl/index. php?id=179\&id2=147 (dostęp: 30.03.2020).

Polscy artyści na Olimpijskich Konkursach Sztuki: 1928-1948, https://culture.pl/pl/artykul/polscy-artysci-na-olimpijskich-konkursach-sztuki-1928-1948 (dostęp: 26.04.2020).

Starożytne idee. Ekecheira, http://www.olimpijski.pl/pl/134,starozytne-idee.html (dostęp: 29.12.2014).

Tuszyński B., Wojciech Trojanowski (1904-1988), „Kwartalnik Historii Prasy Polskiej” 29, 1990, nr 2, s. 95-113.

Wierzyński K., Laur olimpijski, https://www.olimpijski.pl/Media/files/Wierzynski_Laur\%20Olimpijski. pdf (dostęp: 26.04.2020).

Załuski P., U siebie... Moja Wolna Europa, Wrocław 2018. 
Zbigniew Turski 1908-1979 [biogram], https://pwm.com.pl/pl/kompozytorzy_i_autorzy/5250/zbigniew-turski/index.html (dostęp: 26.04.2020).

\section{Spis chronologiczny 42 audycji dotyczących tematyki olimpijskiej w Rozgłośni Polskiej Radia Wolna Europa:}

Wieniec olimpijski (data emisji: 25.12.1956), opowieść radiowa oparta na utworze Jana Parandowskiego pt. Dysk olimpijski, https://www.polskieradio.pl/68/2461/Audio/290443,Wieniec-olimpijski (dostęp: 22.04.2020).

Otwarcie olimpiady w Rzymie (data emisji: 25.08.1960), reportaż Wojciecha Trojanowskiego i Edwarda Sokoppa z uroczystości otwarcia XVII Igrzysk Olimpijskich w Rzymie, https://www.polskieradio. pl/68/2461/Audio/290705, Otwarcie-olimpiady-w-Rzymie (dostęp: 22.04.2020).

Audycja sportowa (data emisji: 6.10.1968), rozmowa Tadeusza Olsztyńskiego (Tadeusza Nowakowskiego) z Wojciechem Trojanowskim, https://www.polskieradio.pl/68/2461/Audio/291895,Audycja-sportowa (dostęp: 22.04.2020).

Audycja sportowa (data emisji: 6.10.1968), rozmowa Tadeusza Olsztyńskiego (Tadeusza Nowakowskiego) z Wojciechem Trojanowskim [szesnastominutowe dokończenie rozmowy - RW], https://www. polskieradio.pl/68/2461/Audio/291896,Audycja-sportowa (dostęp: 22.04.2020).

Rozmowa $z$ Emilem Zatopkiem (data emisji: 22.10.1968), rozmowa Wojciecha Trojanowskiego, wysłannika Rozgłośni Polskiej RWE na olimpiadę w Meksyku, z Emilem Zátopkiem, https://www.polskieradio.pl/68/2461/Audio/292137,Rozmowa-Z-Emilem-Zatopkiem (dostęp: 22.04.2020).

502 dni do Igrzysk Olimpijskich (data emisji: 11.04.1971), reportaż Aleksandra Menharda i Władysława Ponieckiego z placu budowy kompleksu budynków sportowych Letniej Olimpiady w Monachium, https://www.polskieradio.pl/68/2461/Audio/292342,502-dni-do-Igrzysk-Olimpijskich (dostęp: 22.04.2020).

Polskie złote medale olimpijskie (data emisji: 1.04.1972), fragmenty wspomnień Wojciecha Trojanowskiego związanych z polskimi sukcesami olimpijskimi, https://www.polskieradio.pl/68/2461/Audio /292192,Polskie-zlote-medale-olimpijskie (dostęp: 22.04.2020).

Igrzyska Olimpijskie w Monachium (data emisji: 17.09.1972), program Władysława Ponceta, Kazimierza Wilczyńskiego i Jana Jasiewicza podsumowujący zmagania sportowe ze szczególnym uwzględnieniem reprezentantów Polski, https://www.polskieradio.pl/68/2461/Audio/292373,Igrzyska-Olimpijskie-w-Monachium (dostęp: 22.04.2020).

Kawalkada czasu (cz. 16) (data emisji: 1.01.1900 [1973 - RW]), audycja dokumentalna RWE zawierająca wybór najważniejszych wydarzeń polityczno-społecznych w kraju i na świecie w latach 1972-1973, między innymi Igrzyska Olimpijskie w Monachium (relacja komentatora RWE z ulic Monachium po dokonaniu przez bojówki palestyńskie aktów terrorystycznych), https://www.polskieradio.pl/68/2461/Audio/296934,Kawalkada-czasu-cz16 (dostęp: 22.04.2020).

Różne wypowiedzi (data emisji: 30.07.1976), fragmenty wypowiedzi Ireny Szewińskiej na konferencji prasowej podczas Igrzysk Olimpijskich w Montrealu na temat czerpania satysfakcji z biegania, syna Andrzeja, powodów dalszego uprawiania sportu i na temat nieudanych dla niej igrzysk w Meksyku w 1968 roku (j. angielski), https://www.polskieradio.pl/68/2461/Audio/315917,Rozne-wypowiedzi (dostęp: 22.04.2020).

Rozmowa $z$ Wojciechem Trojanowskim (data emisji: 16.04.1979), rozmowa z Wojciechem Trojanowskim — sprawozdawcą radiowym BBC i RWE, https://www.polskieradio.pl/68/2461/Audio/299162,Rozmowa-z-Wojciechem-Trojanowskim (dostęp: 22.04.2020).

42 Niektóre nagrania mają wpisaną datę emisji: 1.01.1900, dlatego też po analizie tematyki audycji dokonano próby określenia roku emisji. 
Sport w 1980 roku (data emisji: 26.12.1980), podsumowanie wydarzeń sportowych 1980 roku, między innymi igrzyska zimowe w Lake Placid i letnie w Moskwie, https://www.polskieradio.pl/68/2461/ Audio/306685,Sport-w-1980-roku (dostęp: 22.04.2020).

Felieton prof. Jerzego Krzyżanowskiego (data emisji: 1.01.1900 [1980? - RW]), felieton Olimpijczyk profesora Jerzego Krzyżanowskiego na temat historii śmierci ojca (Jana Kuleszy) i dziadka (rotmistrza Kuleszy) kilkunastoletniego chłopca o imieniu Toni — dobrze zapowiadającego się kolarza sportowego w Polsce komunistycznej, https://www.polskieradio.pl/68/2461/Audio/326171,Felieton-prof-Jerzego-Krzyzanowskiego (dostęp: 22.04.2020).

Różne wypowiedzi (data emisji: 1.01 .1900 [1980 - RW]), fragmenty wypowiedzi: prezydenta MKOl-u, lorda Killanina, otwierającego igrzyska olimpijskie w Moskwie, i Leonida Breżniewa, I sekretarza KC KPZR, https://www.polskieradio.pl/68/2461/Audio/315393,Rozne-wypowiedzi (dostęp: 22.04.2020).

Dyskusja redakcyjna (data emisji: 1.01.1984), dyskusja z udziałem Władysława Ponieckiego, Huberta Grzymały, Jerzego Różalskiego i Rafała Sikorskiego na temat olimpijskiego roku 1984, https://www. polskieradio.pl/68/2461/Audio/307363,Dyskusja-redakcyjna (dostęp: 22.04.2020).

Studio Olimpijskie (data emisji: 7.02.1984), Studio Olimpijskie XIV Zimowych Igrzysk Olimpijskich w Sarajewie (rozmowa Tadeusza Nowakowskiego z Wojciechem Trojanowskim — sprawozdawcą sportowym - między innymi o wcześniejszych olimpiadach sportowych oraz osiągnięciach polskich sportowców), https://www.polskieradio.pl/68/2461/Audio/307402,Studio-Olimpijskie (dostęp: 22.04.2020).

XIV Zimowe Igrzyska Olimpijskie - Sarajewo 1984 (data emisji: 20.02.1984), XIV Zimowe Igrzyska Olimpijskie w Sarajewie w 1984 roku (dyskusja z udziałem Wojciecha Trojanowskiego, Rafała Sikorskiego, Huberta Grzymały, Władysława Ponieckiego, Tadeusza Nowakowskiego i Piotra Załuskiego podsumowująca udział polskich sportowców w igrzyskach), https://www.polskieradio.pl/68/2461/ Audio/307405,XIV-Zimowe-Igrzyska-Olimpijskie-Sarajewo-1984 (dostęp: 22.04.2020).

Los Angeles - miasto XXIII Olimpiady (data emisji: 22.04.1984), relacja Piotra Kobylińskiego z Los Angeles na temat przygotowań do rozpoczęcia Letnich Igrzysk XXIII Olimpiady, https://www.polskieradio.pl/68/2461/Audio/307440,Los-Angeles-miasto-XXIII-Olimpiady (dostęp: 22.04.2020).

Różne wypowiedzi (data emisji: 1.01.1900 [1984 - RW]), uroczystości otwarcia Igrzysk Olimpijskich w Los Angeles (wypowiedzi: organizatora igrzysk Petera Ueberrotha, przewodniczącego MKOl-u Juana Antonia Samarancha, prezydenta USA Ronalda Reagana, amerykańskiego lekkoatlety Edwina Mosesa), https://www.polskieradio.pl/68/2461/Audio/315989,Rozne-wypowiedzi (dostęp: 22.04.2020).

Zakończenie XXIV letnich igrzysk olimpijskich $w$ Seulu (data emisji: 2.10.1988), audycja Konrada Tatarowskiego i Władysława Ponceta (wrażenia Piotra Załuskiego z igrzysk, rozmowa K. Tatarowskiego i W. Ponceta z Hubertem Grzymałą, Jackiem Kaczmarskim i Krzysztofem Witoniem), https://www. polskieradio.pl/68/2461/Audio/310354,Zakonczenie-XXIV-letnich-igrzysk-olimpijskich-w-Seulu (dostęp: 22.04.2020).

Godzina bez Kwadransa (data emisji: 19.01.1992), audycja Jana Tyszkiewicza (rozmowa J. Tyszkiewicza z Władysławem Minkiewiczem - dziennikarzem, publicystą, autorem książki pt. Olimpijska gorączka), https://www.polskieradio.pl/68/2461/Audio/316280,Godzina-bez-Kwadransa (dostęp 22.04.2020).

Czasy zwykłe, czasy ciekawe (cz. 121) (data emisji: 24.02.1992), audycja pod redakcją Piotra Załuskiego (Igrzyska Zimowe w Albertville, Radiowy Dodatek Olimpijski: odpowiedzi na pytania konkursowe, rozmowa P. Załuskiego i Konrada Tatarowskiego o olimpijskim sporcie), https://www.polskieradio. pl/68/2461/Audio/347120,Czasy-zwykle-czasy-ciekawe-cz121 (dostęp: 22.04.2020).

Program specjalny (data emisji: 9.08.1992), Barcelona '92 - Radiowy Dodatek Olimpijski (informacje Piotra Załuskiego o Polakach, którzy zdobyli medale na olimpiadzie, piosenka dla polskich medalistów, informacje o wynikach z ostatniego dnia igrzysk), https://www.polskieradio.pl/68/2461/ Audio/316726,Program-specjalny (dostęp: 22.04.2020). 
Open Slot (data emisji: 20.08.1992), program Piotra Załuskiego i Konrada Tatarowskiego (losowanie nagród - konkurs olimpijski), https://www.polskieradio.pl/68/2461/Audio/316750,Open-Slot (dostęp: 22.04.2020).

Inauguracja zimowej olimpiady (data emisji: 1.01.1900 [1992 - RW]), sprawozdanie z uroczystości otwarcia zimowych igrzysk olimpijskich we Francji w 1992 roku [to jest chyba pomyłka, bo materiał dźwiękowy jest cały w języku niemieckim - RW], https://www.polskieradio.pl/68/2461/Audio /295435,Inauguracja-zimowej-olimpiady (dostęp: 22.04.2020).

\section{Olympic themes in Polish broadcasts Radio Free Europe}

\section{Summary}

The author presents the Olympic theme in Polish broadcasts of Radio Free Europe, which was one of the main media of the information war during the Cold War. Did the policy influence the content of these programmes? The answer to this question is in the negative. The Olympic Games on Radio Free Europe were presented in a professional manner. Journalists knew sports and sporting competition was the most important for them. Political content in programmes about Olympic competitions was avoided.

Keywords: sport, Olympic Games, Radio Free Europe, politics, Wojciech Trojanowski 